\title{
Evaluating the specification and power of discretionary accruals models in Kuwait
}

\author{
Eiman Algharaballi*, and Saad Albuloushi \\ *P.O. Box 936, Surrah 45710, Kuwait. \\ Tel: + 9655315536
}

Received (in revised form): 1st July, 2008

Eiman Algharaballi is a licensed public accountant, accredited professional accountant and holds a master's degree from Murray State University (Kentucky USA). Mrs Algharaballi is a faculty member at the College of Business Studies, PAAET.

Saad Albuloushi is a licensed public accountant and is currently the Chairman of the Accounting Department at the College of Business studies, PAAET. Professor Albuloushi received his PhD degree from Kent State University $(\mathrm{OH}$, USA) in 2000. His research has been concentrated on capital markets.

\section{Practical Applications}

This study examines specification and power of four models to detect management tendency to manipulate accounting accruals to manage earnings according to their short-term incentives. All four models have the power to detect earnings management. The findings have implications for analysts, financial institutions, auditors, and regulators. For example, in certain contexts, such as initial public offerings, management tends to maximise earnings to increase shares prices. The examined models can be used to detect whether accruals have been manipulated to manage earnings.

Journal of Derivatives \& Hedge Funds, Vol. 14 Nos. 3/4, 2008, pp. 251-264 (C) 2008 Palgrave

Macmillan $1753-9641$

\begin{abstract}
Management of firms tend to focus on short-term personal incentives as opposed to the long-term success of their firms. Accounting accruals represent a favoured instrument for manipulation of earnings and therefore maximising incentives. We evaluate four models developed in prior research to detect earnings management in Kuwaiti listed firms; Jones model, modified Jones model, extended Jones cash flow model, and working capital accruals model. Consistent with the results found in previous studies, we show that all four models were well specified when applied to random samples of firms listed in Kuwait Stock Exchange. In the detection of earnings management, all models show almost the same power capability when expense
\end{abstract}

manipulation was exercised. Jones model, however, shows the highest power of detecting the incomeincreasing accruals through the manipulation of revenue.

Journal of Derivatives \& Hedge Funds (2008) 14, 251-264. doi:10.1057/jdhf.2008.23

Keywords: earnings management; discretional accrual; foreign financial market; Kuwait Stock Exchange; Jones model

\section{INTRODUCTION}

Accounting information is reported in order to expose the financial and economic reality of a 
company, including both its performance and financial status. Among the chief financial officer (CFO), the board members and the company executives, a prospectus elucidating the financial reality is developed and a plan for reporting this reality is shaped. This methodology defines earnings management as preparation and control of the accounting and reporting system skewed towards the fulfillment of management goals within the corporate hierarchy. The prevailing presumption is that the managers, acting as fiduciary officers of the corporate trust, will maximise long-term profit, safeguarding the best interests of the shareholders. Seeking perfection in strategic planning and consistently successful ventures, in conjunction with a focus on aggressive earnings management, will counteract one of the most persistent problems faced by managers, which is a tendency to focus on shortterm personal incentives as opposed to the longterm success of the company.

Accruals represent a favoured instrument for manipulation because of their relative low cost and unobservable nature. For example, managers may affect reported numbers by changing some accruals rather than by making a change in research and development expenditures, asset disposals or changes in accounting methods. Although accruals seem to be a preferable mechanism used by managers, managers have to realise that any accrual manipulation, whether over or (under) statements in the current period, must reverse in the future, and this is related to the reversible nature of accruals. ${ }^{1}$ Managers should be aware of the reversal nature of accruals and should consider the potential cost and the impact this has on reported earnings in the future. For example, increasing earnings in the current period by overstating revenues will necessarily lead to decreasing earnings in the future period, resulting from the understating of revenues. Moreover, extending the useful life of an asset to decrease depreciation expense, leading to the increase of earnings, will definitely result in decreasing earnings at some future date.

Therefore, the unobservable nature of accruals makes the direct measurement of earnings management almost impossible. Accruals can also be divided into current accruals and longterm accruals. Current accruals are adjustments involving short-term assets and liabilities that support day-to-day operations of the firm. Long-term accruals are adjustments involving long-term net assets. ${ }^{2}$

Researchers have long maintained that managers have more authority over existing accruals than over long-term growth. Numerous studies have used a variety of accrual prediction models for different objectives. Typically, those models have been used to detect earnings management. There is, however, no quantitative confirmation that these other models have any increased ability to detect earnings management. ${ }^{3}$

By investigation, the most known methods can be divided into the simple ones, which focus on the measurement of total accruals, and the more sophisticated ones, which require the splitting of accruals into discretionary (abnormal) and nondiscretionary (normal) accruals. The primary focus of earnings management research to date has been on detecting whether and when earnings management takes place. To increase the power of their tests, authors of these studies have typically examined samples of firms where motivations for earnings management are expected to be strong, and focused on overall measures of earnings management, such as total accruals. 
Some previous studies ${ }^{4}$ used the total accruals to proxy for discretionary accruals. Jones ${ }^{5}$ broke new ground by proposing the first expectation model to isolate discretionary accruals. Boynton et al. ${ }^{6}$ estimate the Jones model using data pooled for each industry, rather than estimating the model separately for each firm. In Dechow et al. ${ }^{3}$, the authors propose modification on the Jones original model (called the modified Jones model), relax the assumption that nondiscretionary accruals are constant over time and assume that the variation in the determinants of nondiscretionary accruals is common across firms in the same industry. Guay et al. $^{7}$ evaluate the time-series standard Jones and modified Jones models using market-based procedures.

Shivakumar ${ }^{8}$ developed a new model for estimating discretionary accruals that is well specified even for firms with extreme cash flows. Thomas and Zang $^{9}$ provide some empirical evidence supporting the idea that models working capital (WC) accruals instead of total accruals, and is focused on the more general issue of forecasting accruals, rather than detecting earnings management. Peasnell et al. ${ }^{10}$ contribute to improving the estimation of aggregate discretionary accruals by proposing an alternative cross-sectional model, called the Margin Model, to estimate working discretionary accruals.

The purpose of this study is to evaluate the specification and power of some discretionary accrual models in a sample of non-financial Kuwaiti quoted companies. Specifically, we assess the original Jones model, the modified Jones, the Jones cash flow operating model and the WC model, using traditional statistical techniques such as regression analysis. Although regression analysis is one of the most common statistical systems used in predicting the value of a phenomenon in the future according to correlation between its value now and in the previous years, depending on linear relationship, it has some conditions and restrictions to follow.

The rest of this paper is organised as follows. In the following section, the competing discretionary accruals models assessed are discussed. The subsequent section describes the sample construction, descriptive statistics and methodology used. Then the further section describes the result and the final section represents the summary and conclusions.

\section{COMPETING DISCRETIONARY ACCRUALS METHOD}

There are five main methods mentioned by Xion et al. ${ }^{11}$ in literature that focus on measuring earnings management. These methods represent the discretionary accruals method, the single accrual method, the total accruals method, the accounting changes method and the distribution method. Our focus in this study will be only on the discretionary accruals models. The discretionary accruals methods may be divided into the discretionary total accruals methods and the WC accruals method. The discretionary total accruals method is the preferred method of researchers and is the most common. Jones ${ }^{5}$ broke new ground by proposing the first expectations model to isolate discretionary accruals. ${ }^{10}$ The most frequently used of these methods are the Jones and the modified Jones models. They assume that managers use their discretion over certain accounting accruals as a means of managing earnings. ${ }^{5}$ An important issue here is the need of the accurate separation 
of the reported accruals into their discretionary and nondiscretionary components.

Therefore, researchers are forced to find a way to estimate the discretionary part by exposing the total accruals to a specific expectation model that isolates the discretionary element of total accruals.

The most used starting point for the measurement of discretionary accruals is total accruals. A particular model is then applied to generate the nondiscretionary component of total accruals. In this study, we will focus only on four expectation models: the original Jones model, the modified Jones proposed by Dechow et al., ${ }^{3}$ the extended Jones cash flow model assessed by Kasznik ${ }^{12}$ and the WC model developed by Teoh et al. ${ }^{2}$

\section{The Jones model}

This model uses a two-stage approach to separate total accruals into their discretionary and nondiscretionary components. The first stage is to find the total accruals, which are typically defined as the changes in noncash WC accounts, minus depreciation and amortisation. The total accruals are regressed on the change in sale (change in revenues) and the gross level of property, plant and equipment (PPE) for each sample firm by using the longest available time series before the event year.

Total accruals are calculated as the change in noncash WC before income taxes payable, less total depreciation expense. The change in noncash WC before taxes is defined as the change in current assets other than cash and short-term investments, less current liabilities, other than current maturities of long-term liabilities and income tax payable. ${ }^{5}$ The first stage of the Jones model is to calculate the total accruals $\left(T A_{t}\right)$ as follows:

$$
T A_{t}=\Delta C A_{t}-\Delta C L_{t}-\Delta \operatorname{Cash}_{t}+\Delta S T D_{t}-\operatorname{Dep}_{t}
$$

where $\triangle C A$ is the change in current assets, $\triangle C L$ is the change in current liabilities, $\triangle$ Cash is the change in cash and cash equivalent, $\triangle S T D$ is the change in current maturities of long-term debt and Dep is the depreciation and amortisation expense. Changes in short-term debt are excluded from accruals because they relate to financing transactions as opposed to operating activities. $^{13}$

The second stage of the Jones model is to use the regression equation to estimate the nondiscretionary accruals. The Jones model assumes two variables in the regression, the level of gross PPE and changes in revenues. The level of gross PPE determines depreciation expense, which includes controlling for the portion of the total accruals related to nondiscretionary depreciation expense. The change in revenues implies changes in WC accounts.

$$
\begin{aligned}
T A_{i, t} / A_{i, t-1}= & \alpha_{i}\left[1 / A_{i, t-1}\right]+\alpha_{1 i}\left[\Delta R E V_{i t} / A_{i, t-1}\right] \\
& +\alpha_{2 i}\left[P P E_{i t} / A_{i, t-1}\right]+e_{i, t}
\end{aligned}
$$

where $T A_{i, t}$ is the total accruals in year $t$ for firm $i, \triangle R E V_{i t}$ is the revenues in year $t$ less revenues in year $t-1$ for firm $i, P P E_{i t}$ is the gross PPE in year $t$ for firm $i, A_{i t}$ is the total assets in year $t-1$ for firm $i, e_{i, t}$ is the error term in year $t$ for firm $i, i$ is the number of firm $(N=28)$ and $l$ is the years included in the estimation period. All variables including the intercept term $\alpha_{i}\left[1 / A_{i, t-1}\right]$ are scaled by lagged total assets (or beginning of the period total assets). ${ }^{14}$

Johns described that in equation (2), gross PPE and changes in revenues are included in the 
expectations model to control changes in nondiscretionary accruals caused by changing conditions. Gross PPE is included in the model to control the portion of total accruals related to nondiscretionary depreciation expense. Also, the gross PPE is included in the model instead of the change because total depreciation expense is included in the total accruals measure. All variables in the accruals expectations models are scaled by lagged assets to reduce heteroskedasticity.

The regression provides coefficients that are then used to estimate nondiscretionary accruals. The parameters estimated from regression (2) are then combined with data from event year $t$ to generate estimated discretionary accruals. The regression residuals are considered to be the discretionary accruals as follows:

$$
\begin{aligned}
E D A_{i, t}= & {\left[T A_{i, t} / A_{i, t-1}\right]-\left[\alpha_{i}\left(1 / A_{i, t-1}\right)\right.} \\
& +\alpha_{1 i}\left(\Delta R E V_{i t} / A_{i, t-1}\right) \\
& \left.+\alpha_{2 i}\left(P P E_{i t} / A_{i, t-1}\right)+e_{i, t}\right]
\end{aligned}
$$

where $E D A_{i, t}$ is the expected discretionary accruals, and all other variables are previously determined.

Although the Jones model was the first expectation model to provoke the total accruals into their discretionary and nondiscretionary components, Jones recognises a limitation of her model. This limitation, based on an assumption implicit in the Jones model, is that revenues are nondiscretionary. Therefore, if there is a real discretion over revenue, this model will remove part of the managed earnings from the discretionary accrual proxy. ${ }^{3}$

\section{The modified Jones model}

This model fixed the limitation of the standard Jones model by capturing the impact of salesbased manipulation, since changes in sales are assumed to give rise to nondiscretionary accruals. ${ }^{10}$

Dechow et al. ${ }^{3}$ proposed a modification of the Jones model, which adjusted the changes in the revenues by subtracting the corresponding change in net receivables. The original Jones model implicitly assumes that discretion is not exercised over revenue. The modified version of the Jones model, however, implicitly assumes that all changes in uncollected credit sales at the end of the event period result from earnings management. This is due to the fact that it is easier to manage earnings by exercising discretion over recognition of revenue on credit sales than to manage earnings by exercising discretion over the recognition of revenue on cash sales.

Jeter and Shivakumar ${ }^{15}$ stated "Although the modified Jones model attempts to control the endogenous bias in the original Jones model, it potentially introduces a bias of its own. First, the assumption that all changes in uncollected credit sales result from earnings management is unlikely to be valid, resulting in over-correction.

Secondly, this modification is only appropriate during periods when earnings are actually managed in this manner".

The modified Jones model is identical to the standard Jones model in the first stage, but in the second stage there is a minor modification in that the change in receivables is subtracted from changes in revenues in the second stage.

$$
\begin{aligned}
T A_{i, t} / A_{i, t-1}= & \beta_{i}\left[1 / A_{i, t-1}\right] \\
& +\beta_{1 i}\left[\left(\Delta R E V_{i t}-\Delta R E C_{i t}\right) / A_{i, t-1}\right] \\
& +\beta_{2 i}\left[P P E_{i t} / A_{i, t-1}\right]+e_{i, t}
\end{aligned}
$$

where $\triangle R E C_{i t}$ is the net receivables in year $t$ less net receivables in year $t-1$, and all other variables are predetermined. 


\section{The extended Jones cash flow model}

Dechow et al., ${ }^{3}$ among others, has documented a negative relation between cash flows and accruals even in the presumed absence of any systematic earnings management. They also showed that the time-series Jones model is not well specified for firms with extreme cash flows. Thus, some studies such as Kasnik ${ }^{12}$ have incorporated cash from operations as an extension of the Jones model.

$$
\begin{aligned}
T A_{i, t} / A_{i, t-1}= & \delta_{i}\left[1 / A_{i, t-1}\right] \\
& +\delta_{1 i}\left[\left(\Delta R E V_{i t}-\Delta R E C_{i t}\right) / A_{i, t-1}\right] \\
& +\delta_{2 i}\left[P P E_{i t} / A_{i, t-1}\right]+\delta_{3 i} \Delta C F O+e_{i, t}
\end{aligned}
$$

where $\triangle C F O$ is the change cash flow from operations, and all other variables are predetermined.

Changes in operating cash flow were included in Kasnik ${ }^{12}$ as an explanatory variable to explain the negative correlation between cash flow from operations and total accruals.

\section{WC accruals model}

Study by Dechow et al. ${ }^{3}$ show that the Jones models are not specified for firms with extreme cash flows. Peasnell et al. ${ }^{10}$ demonstrate that the modified Jones model controls only a small amount of normal WC accruals activities. Therefore, a new expectation model has been developed by Teoh et al. ${ }^{14}$ In this method, WC accruals are split into discretionary and nondiscretionary components. The rationale behind this method is that managers have more discretion over current accruals than over longterm accruals, and therefore the discretionary component of WC accruals may be a superior proxy to that of total accruals. Study by Teoh et al. ${ }^{14}$ followed the same rationale as the Jones models.
Total accruals $(T A C)$ can be divided into current accruals $(C A)$ and long-term accruals $(L A)$. TAC can be found using this formula:

$$
T A C=C A+L A
$$

Then the current accruals are the change in noncash current assets minus the change in operating current liabilities:

$$
W C A_{t}=\Delta C A_{t}-\Delta C L_{t}-\Delta C a s h_{t}+\Delta S T D_{t}
$$

where $W C A_{t}$ is the $\mathrm{WC}$ accruals, and all other variables are predetermined.

The coefficients for nondiscretionary WC accruals are obtained by regressing WC accruals on changes in revenues adjusted for the change in receivables.

$$
\begin{aligned}
W C A_{i, t} / A_{i, t-1}= & \pi_{i}\left[1 / A_{i, t-1}\right] \\
& +\pi_{1 i}\left[\left(\Delta R E V_{i t}-\Delta R E C_{i t}\right) /\right. \\
& \left.A_{i, t-1}\right]+e_{i, t}
\end{aligned}
$$

Study by Dechow et al. ${ }^{3}$ propose that the change in receivables should be subtracted from revenues to allow for the possibility of credit sales manipulation.

The estimated coefficients from the regression are then used to estimate the level of discretionary WC accruals by subtracting the estimate of nondiscretionary WC accruals from total WC accruals as follows:

$$
\begin{aligned}
D W C A_{i, t}= & {\left[W C A_{i, t} / A_{i, t-1}\right]-\left[\alpha_{i}\left(1 / A_{i, t-1}\right)\right.} \\
& +\beta_{1 i}\left[\left(\Delta R E V_{i t}-\Delta R E C_{i t}\right) /\right. \\
& \left.\left.A_{i, t-1}\right]+e_{i, t}\right]
\end{aligned}
$$

where $D W C A$ is the discretionary component of WC accruals for sample firm $i$ in year $t$, and all other variables are pre-described. 
Table 1: Observations available by year and sector of final sample of 70 firms

\begin{tabular}{lllll}
\hline & Sector 1 & Sector 2 & Sector 3 & Total \\
\hline 1996 & 9 & 4 & 12 & 25 \\
1997 & 11 & 3 & 13 & 27 \\
1998 & 11 & 4 & 14 & 29 \\
1999 & 12 & 4 & 14 & 30 \\
2000 & 15 & 4 & 14 & 33 \\
2001 & 12 & 4 & 16 & 35 \\
2002 & 17 & 4 & 15 & 36 \\
2003 & 18 & 4 & 17 & 39 \\
2004 & 25 & 4 & 18 & 47 \\
2005 & 23 & 4 & 18 & 45 \\
2006 & 42 & 4 & 22 & 68 \\
Mean & 18 & 3.9 & 15.8 & 12.5 \\
\hline
\end{tabular}

Note: Sectors are: (1) service, (2) food and (3) industry.

\section{SAMPLE CONSTRUCTION, DESCRIPTIVE STATISTICS AND METHODOLOGY}

Following previous research, we use a random sample to test and evaluate the specification and power of different discretionary accruals models in the Kuwaiti context. Specifically, we assess the Jones model, the modified Jones model, the extended Jones cash flow model and the WC model. In this study, the focus is on finding the model that can give the highest explanatory percentage and the one that can be applied most powerfully to Kuwaiti data, rather than on finding the expected discretionary accruals and differences between expected and real earnings management. Firm-specific expectations models are used to estimate nondiscretionary accruals. The total accruals are used in this study to capture earnings management rather than the discretionary portion of a single accrual account, because total accruals should capture a larger portion of managers' manipulations. ${ }^{5}$

\section{Sample construction}

To estimate the models described in the previous section, we use published financial statements data of non-financial Kuwaiti firms quoted on the Kuwait Stock Exchange (KSE) over the period 1995-2006 from the public database of KSE. We excluded firms from the banking and financial sectors because their financial reporting environment differs from those of service, food and industry firms. All data required to estimate the nondiscretionary accruals models and to conduct the empirical analysis are manually taken from the sample firms' annual reports.

Initially, our sample consisted of a total of 73 firms from three different sectors: 45 firms from the service sector, 4 firms from the food sector, and 24 firms from the manufacturing sector. Only 12 years of database were available in the KSE from 1995 to 2006.

We produce a final sample as follows:

1 Firm-year observations before 1995 were not included because of the fact that KSE did not have any database for the years before 1995 due to the political situation back in 1990 (Iraqi invasion of Kuwait).

2 We exclude all financial firms because their financial reporting environments and accrual process are different relative to those of manufacturing, services and food firms.

3 Firm-year observations with missing data necessary to estimate all models were deleted. 
Table 2: Descriptive statistics of models estimated parameters using regression

\begin{tabular}{|c|c|c|c|c|c|c|}
\hline & Mean & Median & $S D$ & Percentile (25) & Percentile (75) & $\% \geqslant 0$ \\
\hline \multicolumn{7}{|c|}{ (1) The standard Jones model: $T A_{i, t} / A_{i, t-1}=\alpha_{i}\left[1 / A_{i, t-1}\right]+\alpha_{1 i}\left[\Delta R E V_{i t} / A_{i, t-1}\right]+\alpha_{2 i}\left[P P E_{i t} / A_{i, t-1}\right]+e_{i, t}$} \\
\hline$\alpha$ & 0.023 & 0.018 & 0.062 & -0.033 & 0.076 & \multirow[t]{2}{*}{80} \\
\hline$T \alpha$ & 0.517 & 0.390 & 8.037 & -0.812 & 1.558 & \\
\hline$\alpha_{1}$ & 0.065 & 0.067 & 0.438 & -0.283 & 0.132 & \multirow[t]{2}{*}{60} \\
\hline$t \alpha_{1}$ & 0.277 & 0.259 & 8.066 & -1.401 & 0.472 & \\
\hline$\alpha_{2}$ & -0.102 & -0.050 & 0.142 & -0.222 & -0.007 & \multirow[t]{4}{*}{20} \\
\hline$t \alpha_{2}$ & -0.821 & -0.398 & 5.170 & -1.877 & -0.046 & \\
\hline Adj. $R^{2}$ & 0.076 & 0.075 & 0.119 & -0.005 & 0.109 & \\
\hline$F$ stat & 2.681 & 2.118 & 3.023 & 0.902 & 2.718 & \\
\hline \multicolumn{2}{|c|}{ (2) The modified Jones model: } & \multicolumn{5}{|c|}{$T A_{i, t} / A_{i, t-1}=\beta_{i}\left[1 / A_{i, t-1}\right]+\beta_{1 i}\left[\left(\Delta R E V_{i t}-\Delta R E C_{i t}\right) / A_{i, t-1}\right]+\beta_{2 i}\left[P P E_{i t} / A_{i, t-1}\right]+e_{i, t}$} \\
\hline$\beta$ & 0.019 & 0.025 & 0.065 & -0.052 & 0.072 & \multirow[t]{2}{*}{80} \\
\hline$T \beta$ & 0.418 & 0.564 & 7.783 & -1.278 & 1.424 & \\
\hline$\beta_{1}$ & -0.087 & -0.058 & 0.161 & -0.227 & 0.064 & \multirow[t]{2}{*}{30} \\
\hline$T \beta_{1}$ & -0.703 & -0.459 & 5.691 & -1.968 & 0.430 & \\
\hline$\beta_{2}$ & 0.011 & 0.045 & 0.365 & -0.249 & 0.169 & \multirow[t]{4}{*}{60} \\
\hline$T \beta_{2}$ & 0.042 & 0.174 & 5.844 & -1.279 & 0.546 & \\
\hline Adj. $R^{2}$ & 0.056 & 0.002 & 0.099 & -0.033 & 0.171 & \\
\hline$F$ stat & 2.171 & 1.041 & 1.998 & 0.584 & 3.474 & \\
\hline
\end{tabular}

(3) The extended Jones cash flow model: $T A_{i, t} / A_{i, t-1}=\delta_{i}\left[1 / A_{i, t-1}\right]+\delta_{1 i}\left[\left(\Delta R E V_{i t}-\Delta R E C_{i t}\right) / A_{i, t-1}\right]$

\begin{tabular}{|c|c|c|c|c|c|}
\hline$\delta$ & 0.017 & 0.021 & 0.059 & -0.055 & 0.071 \\
\hline$T \delta$ & 0.373 & 0.469 & 5.533 & -1.412 & 1.238 \\
\hline$\delta_{1}$ & -0.075 & -0.028 & 0.147 & -0.231 & 0.005 \\
\hline$T \delta_{1}$ & -0.604 & -0.227 & 4.764 & -2.185 & 0.030 \\
\hline$\delta_{2}$ & 0.029 & 0.082 & 0.319 & -0.334 & 0.196 \\
\hline$T \delta_{2}$ & 0.112 & 0.299 & 4.608 & -1.798 & 0.614 \\
\hline$\delta_{3}$ & -0.242 & -0.348 & 0.271 & -0.423 & -0.062 \\
\hline$T \delta_{3}$ & -0.996 & -1.534 & 3.025 & -2.589 & -0.212 \\
\hline Adj. $R^{2}$ & 0.105 & 0.087 & 0.122 & 0.007 & 0.258 \\
\hline$F$ stat & 2.658 & 2.188 & 1.846 & 1.069 & 4.546 \\
\hline
\end{tabular}


Table 2: Concluded

\begin{tabular}{|c|c|c|c|c|c|c|}
\hline & Mean & Median & $S D$ & Percentile (25) & Percentile (75) & $\% \geqslant 0$ \\
\hline \multicolumn{7}{|c|}{ (4) Working capital accruals model: $W C A_{i, t} / A_{i, t-1}=\pi_{i}\left[1 / A_{i, t-1}\right]+\pi_{1 i}\left[\left(\Delta R E V_{i t}-\Delta R E C_{i t}\right) / A_{i, t-1}\right]+e_{i, t}$} \\
\hline$\pi$ & 0.030 & 0.028 & 0.032 & 0.009 & 0.064 & 90 \\
\hline$T \pi$ & 1.050 & 0.954 & 5.110 & 0.405 & 1.834 & \\
\hline$\pi_{1}$ & 0.010 & -0.026 & 0.416 & -0.247 & 0.217 & 50 \\
\hline$T \pi_{1}$ & 0.043 & -0.102 & 6.303 & -1.424 & 0.773 & \\
\hline Adj. $R^{2}$ & 0.031 & -0.005 & 0.083 & -0.018 & 0.028 & \\
\hline$F$ stat & 2.191 & 0.819 & 3.360 & 0.525 & 2.029 & \\
\hline
\end{tabular}

4 Three firms from the total of 73 populations were deleted due to the significant amount of unavailable data.

5 In order to apply the regression equations, the linearity assumption should be met. Therefore, we exclude all extreme values through the residual plots using median \pm 3 interquartiles range.

This process will provide us with a final sample of 415 firm-year observations for which total and working discretionary accruals can be estimated by all four alternative models. Table 1 presents sample details. The average number of observations varies from a minimum of 25 in 1996 to a maximum of 68 in 2006. The mean number of observations per year and sector is 12.5 per year.

\section{Descriptive statistics}

We estimated the models cross-sectionally to control the effect of industrywide economic conditions on total accruals and to allow the coefficients to vary across years.
Descriptive statistics of regression are presented in Table 2, clarifying the mean, median, standard deviation and percentiles. The raw labelled with $(t)$ represents the $t$-statistics for testing the null hypothesis that this coefficient is equal to zero. It is used to find out the probability of the relationship between each of the individual independent variables and the dependent variable occurring by chance. The raw labelled (Adj. $R^{2}$ ) represents the adjusted coefficient of determination, which some researchers prefer to use because it helps to avoid overestimating the impact of adding an independent variable on the amount of variability explained by the estimated regression equation. The raw labelled ( $F$ stat) represents the $F$ statistic test to determine whether the regression model contains at least one explanatory variable. It is used to find out the overall probability of the relationship between the dependent variable and the independent variables occurring by chance. As expected, the coefficient on change in revenues in the standard Jones model and in the WC accruals model is positive. It is, however, negative in the others. The coefficient of the PPE is generally positive except for the standard 
Jones model. Finally, the coefficient of CFO is also negative.

The majority of models have their medium values higher than their means; not one of the four models was significant during $F$-test. The independent explanatory variables percentage varies between 3.1 per cent in the WC accruals model to 10.5 per cent in the extended cash flow model. The introduction of cash flow as an additional independent variable within the Jones model gives rise to a little increase in the explanatory power of the model totalling 10.5 per cent.

\section{Methodology}

In this section, we explain the methodology used to evaluate the specification and power to detect earnings management at the four competing models. Our research design begins with the first-stage regressions, which are estimated crosssectionally for each firm and year combination using all firms with available accrual data. This yields the set of coefficient estimates for a given firm-year combination for each model, which are then consequently used in the computation of discretionary accruals. The primary purpose of this industry-year procedure is to reduce the probability that our estimates of abnormal accruals are not affected by time effects such as interest rates. A drawback of such cross-sectional methods, however, is that they introduce noise into the parameter estimation due to the structural differences between firms. ${ }^{10}$

\section{Test of model specification}

In order for a regression-based expectations model to be effective in estimating discretionary accruals and thus in testing for earnings management, it is essential that the model be well specified in the context in which it is used. ${ }^{10}$ We evaluate model specification by examining the extent to which each of the four models incorrectly rejects the null hypothesis of no earnings management. We used randomly selected samples of firm periods. If the models are well specified, we should not reject the null hypothesis of a mean of zero for these samples. In order to assess whether the models are well specified, we follow the same procedures described by Teoh et al. ${ }^{2}$ as follows:

(a) Estimate the first-stage regressions for each of the four models (standard Jones, modified Jones, extended Jones and WC accruals mode) as previously described.

(b) Randomly select 120 of the observations from the total of 415, without replacement, and create a dummy variable PART that equals 1 for the 120 observations selected and 0 for the rest. The number of observation selected is arbitrary.

(c) Randomise all observations and compute the discretionary accruals for each of the four models using the coefficient estimates obtained in step (a).

(d) Estimate the following univariate regression for each measure of discretionary accruals:

$$
D A_{i}=\alpha+\beta P A R T+\varepsilon_{i}
$$

and test whether the estimated coefficient of $\operatorname{PART}(\beta)$ is significantly different from zero.

(e) Repeat steps (a)-(d) 100 times for each sample year.

Since the observations at step (b) are randomly selected, we should not find systematic earnings management in these observations and therefore the coefficient estimate of PART is not expected to be significantly different from zero. This 
Table 3: Rejection frequencies based on one-tailed t-statistics for the null hypothesis of no earnings management $(\beta=0)$

\begin{tabular}{lll}
\hline Alternative hypothesis & Income-decreasing accruals $(\%)$ & Income-increasing accruals (\%) \\
\cline { 2 - 3 } Null hypothesis & Earnings management $\geqslant 0$ & Earnings management <0 \\
\cline { 2 - 3 } Test level & $5 \%$ & $5 \%$ \\
\hline Standard Jones model & 2.89 & 3.37 \\
Modified Jones model & 3.37 & 3.13 \\
Extended Jones CF model & 3.13 & 3.13 \\
WC accruals model & 2.65 & 4.34 \\
\hline
\end{tabular}

Notes: The table shows the percentage of rejection of the null hypothesis of no earnings management using onetailed test. Simulations for each model were performed using a sample of 120 observations of total 415 in all of the years. The total number of simulations performed was 1,100 for each model.

implies that, if the model is statistically well specified, the null hypothesis of no earnings management $(\beta=0)$ should not be rejected more often than expected at test level specified at 5 per cent.

\section{Test the models' power to detect earnings management}

We assess the power of the four models by examining their ability to detect earnings management activity when it is known to exist. In a sense, we artificially induce a certain amount of manipulation to the observations randomly selected in stage (b). The artificially induced earnings manipulation is added only to those firms where PART equals 1 . Steps (a)-(d) are then repeated 100 times for each sample year. Since the observations where PART equals one are now known to contain income-increasing earnings management activity, we would expect a powerful model to reject the null hypothesis that $\beta=0$, and produces higher rejection frequencies of the null hypothesis of no earnings management. The higher the rejection frequencies associated with a particular model, the more powerful that model is at detecting earnings management activity.

In implementing this procedure, we experiment with different magnitudes of income-increasing accruals ranging from 0 to 100 per cent of firms' lagged assets, in increments of 25 per cent each time. Peasnell et al. ${ }^{10}$ consider three types of accruals manipulation; in our study, we will consider only two types of accruals manipulation:

1 Expense manipulation, other than bad debts. This approach is implemented by adding the amount of manipulation to total accruals as in the three Jones models or to the WC accrual as in the fourth model.

2 Revenue manipulation, such as the premature recognition of sales, assumes all costs are fixed. This approach is implemented by adding the assumed amount of artificial manipulation to total accruals or total WC accruals, total sales and accounts receivable. 

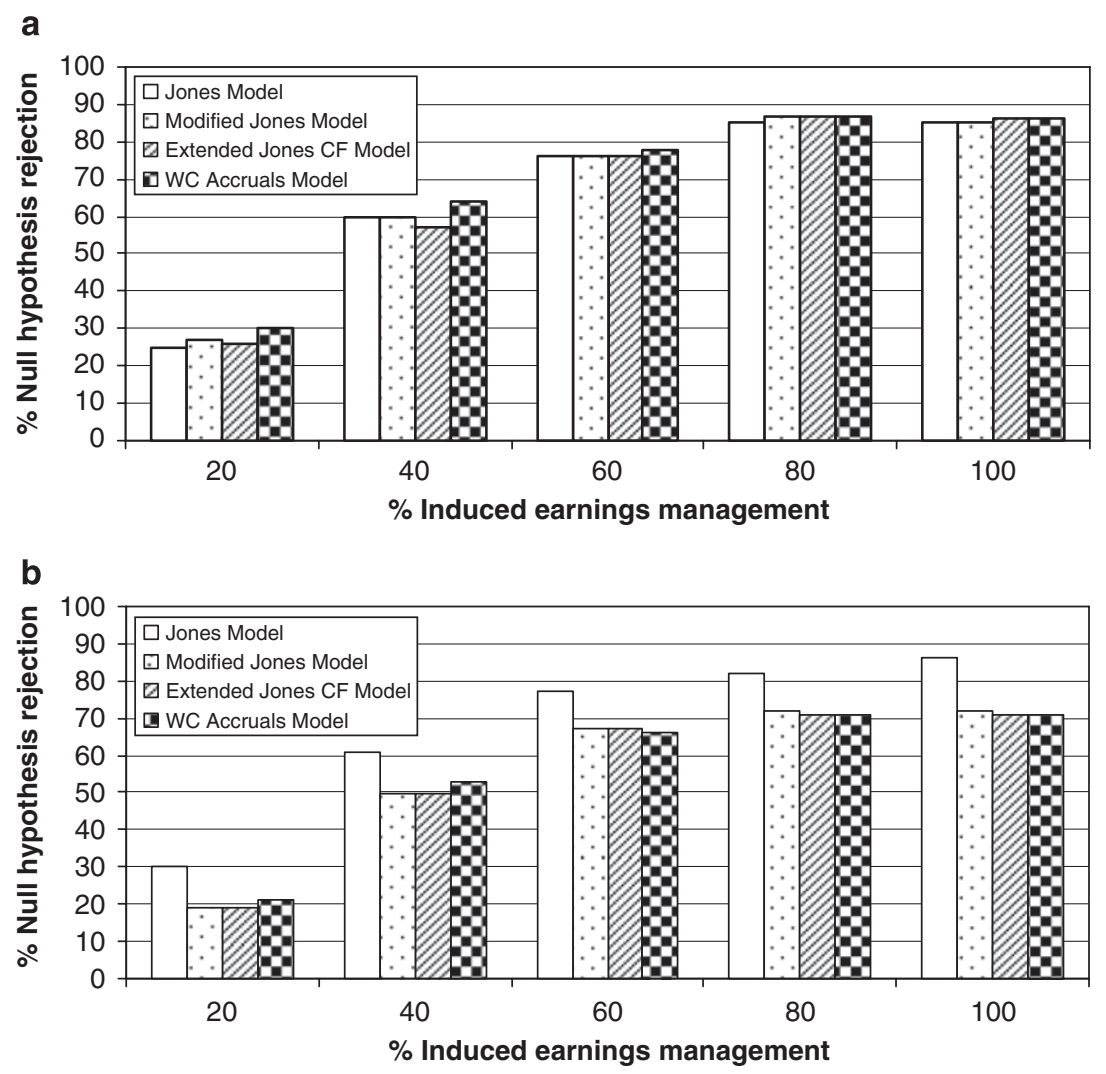

Figure 1: Simulation results of the power to detect artificially induced earnings management of different discretionary accruals models. Simulations were performed by adding amounts of manipulation ranging from 20 to 100 per cent of lagged assets using a one-tailed test level of 5 per cent. The number of simulations performed was 1,100 for each model. (a) Expense manipulation and (b) revenue manipulation

\section{RESULTS}

\section{Model specification}

Table 3 describes the results of our tests for models specification. Type I errors from onetailed tests are reported for both the null hypothesis that discretionary accruals are greater than or equal to zero (alternative hypothesis: income-decreasing earnings management) and the null hypothesis that discretionary accruals are less than zero (alternative hypothesis: income-increasing earnings management). As mentioned earlier, a well-specified model should not reject the null hypothesis of no earnings management at rates that significantly exceed the test level of 5 per cent. We observe that in all models, the percentage of rejection of the null hypothesis of no earnings management is close to the test levels. These findings suggest that all four accrual models appear well specified when applied to a random sample of firm years. 


\section{Models' power}

Figure 1 describes the results of the power to detect artificially induced earnings management at levels from 20 to 100 per cent of lagged total assets.

Rejection rates for test level are computed using a one-tailed test. A common feature of the results presented in Figure 1 is that all three models seem to generate relatively powerful tests for economically plausible levels of accruals management. Even for relatively low accruals manipulations of around 40 per cent of lagged total assets, the rejection frequencies can be as high as 50-60 per cent depending on the particular accrual model used and the kind of accruals manipulation.

The graphs in panel A represent the result of the power function of expense manipulation. All models appear to have the same rejection frequencies of the null hypothesis of no income increasing earnings management at levels from 20 to 100 per cent artificially induced incomeincreasing manipulation. WC accruals models, however, give the highest rejection of each of the four models in every stage of manipulation.

Panel B represents the result of the power of revenue manipulation. Results indicate that the standard Jones model produces the most powerful tests. It generates rates of rejection of the null hypothesis of no income-increasing earnings management close to 75 per cent for artificially induced accruals manipulations of around 60 per cent of lagged total assets or greater. The WC accruals model power function is always below the Jones model, but still has the higher rejection frequencies of the other three models.

\section{SUMMARY AND CONCLUSIONS}

The purpose of this paper is to evaluate the specification and power of some discretionary accruals models and to apply them to a sample of Kuwaiti non-financial companies using cross-sectional estimation procedures. Using simulation analysis, we evaluated four alternative cross-sectional accruals models.

Consistent with prior research, results indicate that all the models are well specified when applied to random samples of firms. In the detection of earnings management, all models show almost the same power capability when expense manipulation was exercised. The Jones model, however, shows the highest power of detecting the income-increasing accruals through the manipulation of revenue.

\section{References}

1 Young, S. (1999) 'Systematic Measurement Error in the Estimation of Discretionary Accruals: An Evaluation of Alternative Modeling Procedures', Journal of Business Finance \& Accounting, Vol. 26, No. 7, pp. 833-862.

2 Teoh, S.H., Welch, I. and Wong, T.J. (1998a) 'Earnings Management and the Long-Run Market Performance of Initial Public Offering', The Journal of Finance, Vol. 3, No. 6, pp. 1935-1974.

3 Dechow, P.M., Sloan, R.G. and Sweeny, A.P. (1995) 'Detecting Earnings Management', The Accounting Review, Vol. 70, No. 2, pp. 193-225.

4 Healy, P.M. (1985) 'The Effect of Bonus Schemes on Accounting Decisions', Journal of Accounting and Economics, Vol. 7, pp. 85-107.

5 Jones, J.J. (1991) 'Earnings Management During Import Relief Investigations', Journal of Accounting Research, Vol. 29, No. 2, pp. 193-228.

6 Boynton, C., Dobbins, P. and Plesko, G. (1992) 'Earnings Management and the Corporate Alternative Minimum Tax', Journal of Accounting Research, Vol. 30, pp. 131-153.

7 Guay, W.R. and Kothari, S.P. (1996) 'A Market-Based Evaluation of Discretionary Accrual Models', Journal of Accounting Research, Vol. 34, pp. 83-105.

8 Shivakumar, L. (1996) 'Estimating Abnormal Accruals for Detection of Earnings Management', Working Paper, Vanderbilt University. March.

9 Thomas, J. and Zang, X. (2000) 'Identifying Unexpected Accruals: A Comparison of Current Approaches', Journal of Accounting and Public Policy, Vol. 19, pp. 347-376. 
10 Peasnell, K.V., Pope, P.F. and Young, S. (2000) 'Detecting Earnings Management Using Crosssectional Abnormal Accruals Models', Accounting and Business Research, Vol. 30, No. 4, pp. 313-326.

11 Xiong, Y. (2006) 'Earnings Management and its Measurement: A Theoretical Perspective', The Journal of American Academy of Business, Vol. 9, No. 1, pp. 214-219.

12 Kasznik, R. (1999) 'On the Association Between Voluntary Disclosure and Earnings Management', Journal of Accounting Research, Vol. 37, No. 1, pp. 57-81.
13 Leuz, C., Nanda, D. and Wysocki, P.D. (2003)

'Earnings Management and Investor Protection: An International Comparison', Journal of Financial Economics, Vol. 69, pp. 507-527.

14 Teoh, S.H., Welch, I. and Wong, T.J. (1998b) 'Earnings Management and the Underperformance of Seasoned Equity Offerings', Journal of Financial Economics, Vol. 50, pp. 63-99.

15 Jeter, D.C. and Shivakumar, L. (1999) 'Cross-sectional Estimation of Abnormal Accruals Using Quarterly and Annual Data: Effectiveness in Detecting Event-specific Earnings Management', Accounting and Business Research, Vol. 29, No. 4, pp. 299-319. 